\title{
Production of putative virulence factors by Renibacterium salmoninarum grown in cell culture
}

\author{
D. Mclntosh, ${ }^{1} \dagger$ E. Flaño, ${ }^{3}$ T. H. Grayson, ${ }^{2}$ M. L. Gilpin, ${ }^{2}$ B. Austin ${ }^{1}$ \\ and A. J. Villena ${ }^{3}$
}

Author for correspondence: B. Austin. Tel: +44131451 3452. Fax: +44 1314513009.

e-mail: B.Austin@hw.ac.uk

\footnotetext{
1 Department of Biological Sciences, Heriot-Watt University, Riccarton, Edinburgh EH14 4AS, UK

2 Department of Biological Sciences, University of Plymouth, Plymouth PL4 8AA, UK

3 Departamento de Biologia Celular y Anatomía, Facultad de Biologla, Universidad de León, 24071-León, Spain
}

\begin{abstract}
A cell culture system, employing the fish cell line Epithelioma papillosum cyprini (EPC), was developed to study the synthesis of intracellular antigen and the expression of putative virulence factors by Renibacterium salmoninarum. EPC cultures infected with $R$. salmoninarum could be maintained for 7 weeks, during which the pathogen multiplied intracellularly. Immunohistochemical examination of infected cultures revealed the production of the p57 antigen, haemolysin and cytolysin. The intracellular nature of the infection was confirmed by transmission electron microscopic examination of EPC monolayers. A comparison of the relative virulence of bacterial cells cultured in EPC cells and on agar plates revealed that the former were markedly more virulent in challenge experiments with juvenile rainbow trout (Oncorhynchus mykiss Walbaum). The EPC cell culture model provided a system for the study of $R$. salmoninarum under more natural conditions than those achieved with plate culture techniques.
\end{abstract}

Keywords: cell culture, Renibacterium salmoninarum, in vitro infection, antigen detection

\section{INTRODUCTION}

Renibacterium salmoninarum is the causative agent of bacterial kidney disease (BKD), a chronic debilitating disease of salmonids (Fryer \& Sanders, 1981). The disease is characterized by a granulomatous inflammatory response with marked affinity for kidney tissue (Wolke, 1975). The pathogen is capable of multiplication in host cells, particularly macrophages (Young \& Chapman, 1978; Gutenberger, 1993) and non-professional phagocytic cells (Flaño et al., 1996b, c), and can evade host immune surveillance with the result that asymptomatic carriers may develop (Evelyn, 1993). This intracellular nature limits the effectiveness of chemotherapy (Austin \& Austin, 1993).

$R$. salmoninarum is a Gram-positive, slow-growing, nutritionally fastidious organism which is difficult to

\footnotetext{
†Present address: Departamento Bioquimica e Biologia Molecular, Instituto Oswaldo Cruz, FIOCRUZ, Avenida Brasil 4365, Rio de Janeiro, 21045 900, Brazil.

Abbreviations: EP, extracellular products; EPC cells, Epithelioma papillosum cyprini cells; BKD, bacterial kidney disease.
}

culture in vitro, requiring prolonged incubation on cysteine-containing media. The inability to conveniently culture the organism may be the main reason why so little is known about the virulence or pathogenicity mechanisms of $R$. salmoninarum (Evenden et al., 1993).

Following the identification of the p57 protein (Getchell at al., 1985) and subsequent studies confirming it to be the predominant cell surface antigen and constituent of the extracellular products (EP) in vitro and in vivo (Turaga et al., 1987; Wiens \& Kaattari, 1989; Griffiths et al., 1991), workers have sought to define a role for the protein in the pathogenesis of BKD. Properties ascribed to the $\mathrm{p} 57$ protein include the ability to bind to salmonid erythrocytes (Kaattari et al., 1986), haemagglutination of mammalian erythrocytes (but not usually those of fish species) (Daly \& Stevenson, 1987; Bandín et al., 1989), agglutination of salmon spermatazoa (Daly \& Stevenson, 1989) and the leukocytes of various salmonids (Wiens \& Kaattari, 1991), and hydrophobicity of the cell surface of $R$. salmoninarum (Daly \& Stevenson, 1990). Also, the $\mathrm{p} 57$ protein may be involved in the attachment of $R$. salmoninarum to phagocytes in the absence of specific antibody, as a consequence of opsonization by 
complement component $\mathrm{C} 3 \mathrm{~b}$ and subsequent binding to the CR1 complement receptor (Rose \& Levine, 1992).

The biological activities of the EP of 11 isolates of $R$. salmoninarum have been examined (Bandín et al., 1991). These workers reported a low overall production of extracellular proteins with two isolates, which demonstrated proteolytic activity. However, they did not record the presence of any haemolytic or cytotoxic activity, nor were there any detrimental effects following the injection of EP $\left[10-20 \mu \mathrm{g}(\mathrm{g} \text { fish })^{-1}\right]$ into fish. In contrast to the EP, live cells possessed strong enzymic activities and Bandín et al. (1991) suggested that these enzyme properties were likely to be associated with the cell envelope. The possibility that storage or subculture of $R$. salmoninarum may lead to a loss of detectable biological activity of the EP was also inferred by these authors.

Researchers have applied recombinant DNA technology to the study of virulence mechanisms in an attempt to circumvent some of the problems associated with the poor growth of $R$. salmoninarum in vitro. In particular, the $r s h$ gene from $R$. salmoninarum, encoding haemolytic activity for trout erythrocytes, has been cloned into Escherichia coli K-12 (Evenden et al., 1990). This was followed by cloning and sequencing of the bly gene, encoding a haemolytic activity distinct from that described previously (Grayson et al., 1995a), and a DNA fragment associated with bacterial internalization into chinook salmon embryo (CHSE) cell lines (Maulén $e t$ al., 1996).

This study sought to develop a novel method to study the pathogenicity of $R$. salmoninarum using fish cell culture. In particular, attention was focused on developing a system that enabled the reproducible establishment of intracellular infection under controlled conditions thereby enabling the study of putative virulence mechanisms under conditions more closely resembling those encountered in fish than in conventional in vitro methods.

\section{METHODS}

Bacterial culture. $R$. salmoninarum FT10, a virulent isolate recovered from the kidney of Atlantic salmon (Salmo salar L.) in Scotland (McIntosh \& Austin, 1996), was used in all experiments. Virulence was maintained by repeated passage through juvenile rainbow trout (Oncorbynchus mykiss Walbaum; mean weight approx. $25 \mathrm{~g}$ ). For this, the fish in groups of four were injected intraperitoneally with about $10^{5}$ cells per fish. Animals were sacrificed 6 weeks after infection and the pathogen was subsequently recovered from the kidney and/or ascitic fluid as pure culture growth on plates of selective kidney disease medium (SKDM; Austin et al., 1983) modified by the addition of $10 \%(\mathrm{v} / \mathrm{v})$ spent culture medium (mSKDM), according to the method of Evelyn et al. (1989), with incubation at $15^{\circ} \mathrm{C}$ for $21 \mathrm{~d}$. Production of the p57 antigen was verified by Western blotting after McIntosh \& Austin (1996).

Cell lines, culture media and culture conditions. Stock cultures of fish cell line Epithelioma papillosum cyprini (EPC) cells in foetal calf serum (FCS, Gibco) supplemented with $10 \%(\mathrm{v} / \mathrm{v})$ DMSO were stored in liquid nitrogen. Thawed cells $(0.5 \mathrm{ml})$ were resuspended in $5 \mathrm{ml}$ Glasgow minimal essential medium (BHK 21) with $200 \mathrm{mM}$ L-glutamine, without tryptose phosphate broth (Gibco), supplemented with $10 \%$ (v/v) FCS. These suspensions were used as inocula for individual $25 \mathrm{~cm}^{3}$ tissue culture flasks fitted with filter top caps (Nunc) with incubation at $18{ }^{\circ} \mathrm{C}$ in $5 \%$ (v/v) $\mathrm{CO}_{2}$. A complete medium change was carried out after $24 \mathrm{~h}$ and cultures were incubated until they reached semi-confluence. Cells were detached by the addition of $0.5 \mathrm{ml} 1 \times$ trypsin-EDTA solution (Gibco) and used to inoculate four fresh $25 \mathrm{~cm}^{3}$ flasks at a seeding density of $1 \times 10^{6}$ cells per flask, with incubation as before, until confluence was achieved (usually 14-18 d).

Infection of EPC cultures. Infection of duplicate EPC cultures was performed using $R$. salmoninarum FT10 at a concentration of $5 \times 10^{5}$ cells per flask. The bacterial cells were scraped from the surface of 21-d-old mSKDM plate cultures obtained from the kidney or ascitic fluid of experimentally infected rainbow trout and resuspended in $10 \mathrm{ml}$ phosphatebuffered saline (PBS, $\mathrm{pH} 7 \cdot 2$ ). Harvesting was by centrifugation $\left(2000 \mathrm{~g}\right.$ for $15 \mathrm{~min}$ at $\left.4^{\circ} \mathrm{C}\right)$, followed by re-suspension and dilution in PBS to a final concentration of $1 \times 10^{6} \mathrm{cells} \mathrm{ml}^{-1}$ as determined using an improved Neubauer haemocytometer. One millilitre of this suspension was mixed with $9 \mathrm{ml}$ culture medium. Prior to use of the EPC cells in infectivity experiments, the cell culture medium was removed by aspiration and the monolayers washed once with $5 \mathrm{ml}$ PBS, then duplicate flasks were inoculated with $5 \mathrm{ml}$ bacterial suspension per flask. One millilitre of PBS was mixed with $9 \mathrm{ml}$ culture medium and used as inoculum for two negative control flasks. The cell cultures were incubated for $3 \mathrm{~h}$ at $18{ }^{\circ} \mathrm{C}$, before the medium was removed, and the monolayers washed twice with $5 \mathrm{ml}$ PBS. Then $5 \mathrm{ml}$ volumes of fresh cell culture medium supplemented with $10 \mu \mathrm{g}$ gentamicin $\mathrm{ml}^{-1}, 100$ units penicillin $\mathrm{ml}^{-1}$ and $100 \mu \mathrm{g}$ streptomycin $\mathrm{ml}^{-1}$ (all Gibco) were added to each flask. The cultures were incubated for $72 \mathrm{~h}$ at $18^{\circ} \mathrm{C}$, washed twice with $5 \mathrm{ml}$ PBS, then treated with trypsin-EDTA to produce single cell suspensions in $5 \mathrm{ml}$ volumes of antibiotic-free culture medium. The EPC cell suspensions, obtained from the two flasks, were pooled and collected by centrifugation $\left(400 \mathrm{~g}\right.$ for $10 \mathrm{~min}$ at $4^{\circ} \mathrm{C}$ ), resuspended in $5 \mathrm{ml}$ fresh antibiotic-free culture medium and counted in an improved Neubauer haemocytometer. Each pooled cell suspension was used as inoculum for six $25 \mathrm{~cm}^{3}$ flasks at a seeding density of $5 \times 10^{5}$ cells per flask. In addition, six 8-well chamber slides (Nunc) were inoculated (4 wells with infected cells and 4 wells with control cells) at a seeding density of $5 \times 10^{4}$ EPC cells per well. Antibiotic-free culture medium was added to each flask $(5 \mathrm{ml})$ or well $(0.4 \mathrm{ml})$ and the cultures were incubated as before.

Bacteriological examination of infected EPC cultures. An initial estimation of bacterial numbers was carried out on the pooled EPC cell suspensions described above. The EPC cells were diluted in antibiotic-free medium to a concentration of $1 \times 10^{6}$ cells $\mathrm{ml}^{-1}$. The EPC cells were collected from duplicate $1 \mathrm{ml}$ volumes by centrifugation $\left(400 \mathrm{~g}\right.$ for $10 \mathrm{~min}$ at $\left.4^{\circ} \mathrm{C}\right)$, the supernatant discarded and the EPC cells lysed by the addition of $100 \mu$ lice-cold tissue-culture quality distilled water (Gibco) with vigorous vortexing for $1 \mathrm{~min}$. Counts of viable $R$. salmoninarum cells were obtained using duplicate volumes $(20 \mu \mathrm{l})$ of lysate. Serial tenfold dilutions to $10^{-7}$ in PBS were prepared and two $20 \mu \mathrm{l}$ volumes of each dilution used as inocula for plates of mSKDM, using the drop plate method (Griffiths et al., 1991). The plates were sealed with laboratory film to prevent drying and incubated at $15^{\circ} \mathrm{C}$ for up to 12 
Table 1. Infection of EPC cells by $R$. salmoninarum

\begin{tabular}{|lcc|}
\hline $\begin{array}{l}\text { No. of days after } \\
\text { inoculation of the flask }\end{array}$ & $\begin{array}{c}\text { Bacterial cells (c.f.u.) } \\
\text { per 10 }\end{array}$ & $\begin{array}{c}\text { Bacterial cells (c.f.u.) per ml } \\
\text { culture supernatant }\end{array}$ \\
\hline 7 & $2.5 \times 10^{3}$ & $8.5 \times 10^{2}$ \\
14 & $7 \cdot 5 \times 10^{4}$ & $1.6 \times 10^{4}$ \\
21 & $9 \cdot 1 \times 10^{5}$ & $5.8 \times 10^{5}$ \\
28 & $6.8 \times 10^{6}$ & $5 \cdot 0 \times 10^{6}$ \\
35 & $8 \cdot 2 \times 10^{6}$ & $1.0 \times 10^{7}$ \\
42 & $1.5 \times 10^{6}$ & $7 \cdot 2 \times 10^{7}$ \\
\hline
\end{tabular}

* The number of bacteria in the original infected flask at $72 \mathrm{~h}$ after infection was $5 \times 10^{2}$ cells per $10^{6}$ EPC cells.

† Mean c.f.u. recovered from duplicate samples of lysate or culture supernatant.

weeks. Flasks of infected and control EPC cultures were examined for the presence of $R$. salmoninarum 7, 14, 21, 28, 35 and $42 \mathrm{~d}$ after inoculation. The cell culture medium was removed from each flask and collected in sterile universal bottles. Then the monolayers were washed twice with $10 \mathrm{ml}$ PBS. Duplicate $1 \mathrm{ml}$ volumes of cell culture medium were centrifuged $\left(10000 \mathrm{~g}\right.$ for $5 \mathrm{~min}$ at $\left.4^{\circ} \mathrm{C}\right)$, the supernatants discarded and the pellets resuspended in $100 \mu$ l volumes of PBS. These suspensions were examined for counts of $R$. salmoninarum as for the lysates described above. Examination of infected EPC cultures involved the detachment of the monolayer by treatment with trypsin-EDTA $(0.5 \mathrm{ml}$ per flask) followed by the addition of $2 \mathrm{ml}$ volumes of fresh cell culture medium to each flask. A $100 \mu \mathrm{l}$ volume of the cell suspension was removed to estimate viable EPC cell numbers. Then $2 \mathrm{ml}$ of the remaining cell suspension was transferred to a $15 \mathrm{ml}$ centrifuge tube (Corning), the cells sedimented by centrifugation $\left(400 \mathrm{~g}\right.$ for $10 \mathrm{~min}$ at $\left.4{ }^{\circ} \mathrm{C}\right)$ and the supernatants discarded. The EPC cells were lysed by the addition of $200 \mu \mathrm{l}$ ice-cold distilled water (Gibco) and vigorous vortexing for $1 \mathrm{~min}$. The lysates were processed for counts of viable $R$. salmoninarum as above. To allow a comparison of the bacterial populations at the different sampling times, the numbers were expressed as $R$. salmoninarum cells per $10^{6} \mathrm{EPC}$ cells, based on the viable bacterial cell counts performed on the trypsinized cell suspensions described above.

Transmission electron microscopy. At $21 \mathrm{~d}$ after infection, the monolayers were detached from the surface of the flask by the addition of ice-cold $0.2 \mathrm{M}$ sodium cacodylate buffer $(\mathrm{pH} 7 \cdot 2)$, the cells were fixed in $2 \%(\mathrm{w} / \mathrm{v})$ glutaraldehyde in sodium cacodylate buffer for $2 \mathrm{~h}$ and post-fixed with osmium tetroxide also in cacodylate buffer for $1 \mathrm{~h}$ at $4^{\circ} \mathrm{C}$. The cells were mixed with cooled (about $50^{\circ} \mathrm{C}$ ) molten $2 \%(\mathrm{w} / \mathrm{v}$ ) Oxoid No. 1 agar, dehydrated in a graded series of acetone, contrasted with $1 \%(\mathrm{w} / \mathrm{v})$ uranyl acetate in $70 \%$ ethanol and embedded in Araldite (Durcupan, ACM, Fluka). Semithin sections of $1 \mu \mathrm{m}$ thickness were stained with an aqueous solution of toluidine blue in borax. Ultrathin sections were obtained using a Reichert-Jung UM-3 ultratome, counterstained with lead citrate and observed in a JEOL EM1010 electron microscope at $60 \mathrm{kV}$.

Immunohistochemistry. Immunolabelling of bacteria and secreted p57 antigen was carried out with a mouse anti-p57 monoclonal antibody (BW3.1; Bioscot) and rat polyclonal antisera raised against recombinant forms of $R$. salmoninarum haemolysin (encoded by rsh; Grayson et al., 1995b) or cytolysin (encoded by bly; Grayson et al., 1995a) as primary antibody. The monoclonal and polyclonal antibodies were employed at dilutions of $1: 1000$ and 1:50, respectively. Infected and control cultures produced in chamber slides were examined at 4, 7, 14, 21, 28 and $35 \mathrm{~d}$ after inoculation. The monolayers were fixed for $5 \mathrm{~min}$ with methanol/acetic acid (3:1), washed twice with Tris-buffered saline (TBS; $\mathrm{pH} 7 \cdot 4$ ) and the primary antiserum $(100 \mu$ l per well) was applied, with incubation at $37^{\circ} \mathrm{C}$ for $1 \mathrm{~h}$. Two wells per slide (one infected and one control) served as primary antibody negative controls, with TBS used in place of diluted antibody. Bound antibody was detected using an alkaline phosphatase anti-alkaline phosphatase (APAAP) system (DAKO), with AS-BI phosphate/fast red as substrate. The slides were counterstained with haematoxylin and mounted in glycerol.

Comparative virulence of $R$. salmoninarum grown in EPC cells and on mSKDM. Using a Vacutainer (Greiner), ascitic fluid $(4 \mathrm{ml})$ was collected from a juvenile rainbow trout 8 weeks after infection intraperitoneally with $10^{5}$ cells of $R$. salmoninarum (FT10). The ascitic fluid was centrifuged $(2000 \mathrm{~g}$ for $15 \mathrm{~min}$ at $4^{\circ} \mathrm{C}$ ) and the pellet resuspended in $5 \mathrm{ml}$ distilled water (to lyse the fish cells), vortexed for $30 \mathrm{~s}$ and recentrifuged. R. salmoninarum cells were resuspended in $9 \mathrm{ml}$ PBS and diluted 1000-fold in culture medium. Duplicate plates of mSKDM and flasks of EPC cells were inoculated with $100 \mu \mathrm{l}$ or $5 \mathrm{ml}$ volumes of the diluted bacterial suspension, respectively. The plates were incubated at $15^{\circ} \mathrm{C}$ for $21 \mathrm{~d}$. Flasks of EPC cells were processed, as above, with incubation for $21 \mathrm{~d}$ at $18^{\circ} \mathrm{C}$. Thereafter, bacterial growth from the mSKDM plates was collected and resuspended in $10 \mathrm{ml}$ volumes of PBS. Infected EPC cultures were lysed with distilled water to release intracellular bacteria which were collected by centrifugation before resuspension in $10 \mathrm{ml}$ volumes of PBS. To determine the number of viable bacterial cells in the different challenge doses, the bacterial suspensions were adjusted to approximately $10^{6}$ cells $\mathrm{ml}^{-1}$ and serial tenfold dilutions prepared in PBS that were used as inocula for plates of mSKDM with incubation at $15^{\circ} \mathrm{C}$ for up to 12 weeks. Rainbow trout (mean weight of $15-20 \mathrm{~g}$ ), in groups of ten, were challenged by intraperitoneal injection with $0.1 \mathrm{ml}$ undiluted, 10 - or 100 -fold dilutions of the appropriate $R$. salmoninarum suspension. Fish were returned to tanks and monitored over 8 weeks. Any dead or moribund animals were removed and the presence of $R$. salmoninarum was confirmed by the presence of colonies which developed after swabbing kidney material onto plates of mSKDM with incubation at $15^{\circ} \mathrm{C}$ for up to 12 weeks. All survivors were killed with an overdose of anaesthetic (MS222; 

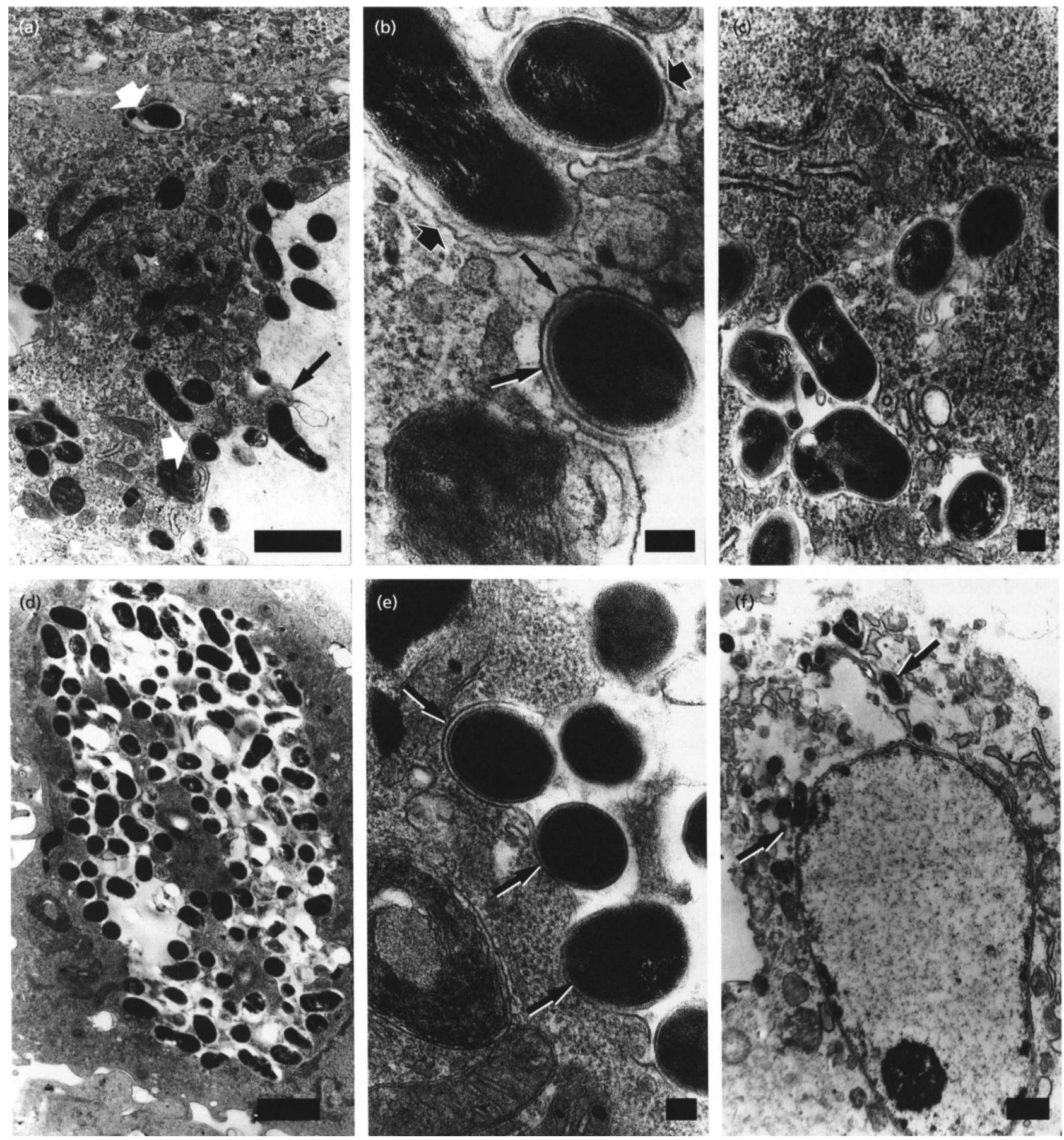

Fig. 1. Ultrathin sections of EPC cultures infected with $R$. salmoninarum ( $21 \mathrm{~d}$ after inoculation). (a) $A$ portion of the cytoplasm of a $R$. salmoninarum-infected EPC cell. Some bacteria are in contact with the plasma membrane, partially surrounded by small pseudopodia (black arrow); others are located within individual phagosomes (white arrows). Bar, $1.0 \mu \mathrm{m}$. (b) Higher magnification of the cytoplasm of a $R$. salmoninarum-infected EPC cell showing detail of a $R$. salmoninarum cell being engulfed (thin arrows) and bacteria located in membrane-bound cytoplasmic vesicles (thick arrows). Bar, $0.1 \mu \mathrm{m}$. (c) Detail of an infected EPC cell containing several bacteria in cytoplasmic vesicles. Note that the surrounding cytoplasm shows no sign of degradation. A portion of the nucleus is shown. Bar, $0.1 \mu \mathrm{m}$. (d) Low power magnification of a heavily infected EPC cell, which shows a large cystic cavity full of bacteria. This cystic cavity contains degenerated cell material, whereas the surrounding cytoplasm does not show any sign of degeneration. Bar, 1.0 $\mu \mathrm{m}$. (e) Higher magnification of the cystic cavity of an infected EPC cell showing bacteria in intimate association with the vesicle membranes (arrows). The cytoplasmic organelles are unaltered. Bar, $0.1 \mu \mathrm{m}$. (f) Infected and lysed EPC cell. Note the disrupted cytoplasm still contains some bacteria, whereas others occur in the adjacent extracellular space (arrows). The nucleus appears degenerate, with loss of nuclear structure, but does not show pycnosis. Bar, 1.0 $\mu \mathrm{m}$. 
Sigma) and examined by culture on MSKDM to determine the level of non-lethal infections in each group of fish.

\section{RESULTS}

\section{Infection of EPC cultures}

Bacterial cell count data from the infectivity experiments demonstrated that $R$. salmoninarum (FT10) was capable of entry into and multiplication in EPC cells. Table 1 shows the progress of a typical infectivity experiment. The initial level of intracellular infection was low $\left(5 \times 10^{2} \mathrm{R}\right.$. salmoninarum per $10^{6} \mathrm{EPC}$ cells $)$, followed by a steady increase in numbers in the EPC cells and in the culture supernatant. It was not determined whether the bacteria present in the supernatant were actively replicating or if they represented bacterial cells released from lysed EPC cells. However, attempts to culture $R$. salmoninarum in sterile cell culture medium were unsuccessful (data not shown). When examined by light microscopy, infected monolayers did not demonstrate any marked morphological changes when compared with control cultures, with the exception of an increase in cellular vacuolation. There was no evidence of widespread disruption of the monolayers and the cultures continued to multiply as indicated by increased cell numbers at the time of trypsinization. In general, the EPC cultures retained a healthy appearance until ap- proximately 6-7 weeks after inoculation with $R$. salmoninarum, when the cells demonstrated a more granular appearance and reduced surface attachment. In some cases at this stage, the monolayer underwent a sudden disintegration. By transmission electron microscopy, it was seen that at the early stages of infection the pathogen was located both intracellularly and extracellularly (Fig. 1a). Phagocytic pseudopodia engulfing bacteria were small (Fig. 1a). Intracellular bacteria were observed within membrane-bound vesicles (Fig. $1 \mathrm{~b}$ and c) and were often seen to be in contact with the membranes (Fig. 1c). Usually each phagosome contained a single bacterium, although occasionally some phagosomes were observed to contain 2-5 bacteria (Fig. 1c). In EPC cells which were at a more advanced stage of infection, as indicated by the presence of large numbers of bacteria, $R$. salmoninarum cells were observed to be located within large cystic cavities (Fig. 1d). A proportion of the bacterial cells were observed to be in intimate association with the vesicle membrane (Fig. 1d and e). However, despite the heavy intracellular bacterial load, the integrity of the cytoplasm of the EPC cells did not appear to be affected, insofar as normal organelle structure was maintained (Fig. 1e). There was evidence of lysis of some infected EPC cells that showed cellular necrosis denoted by nuclear disorganization (Fig. 1f), but pycnotic nuclei were not observed.
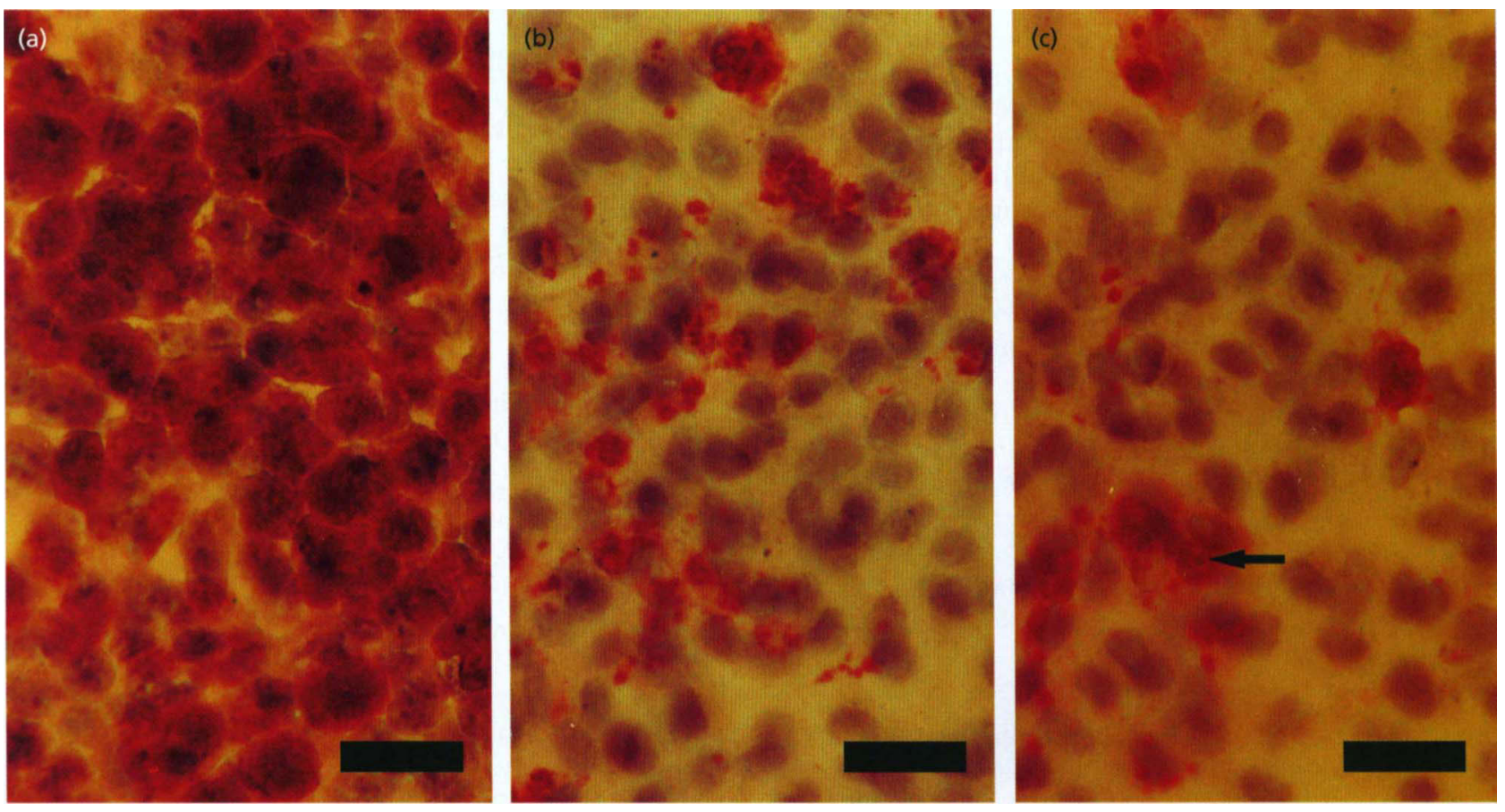

Fig. 2. Immunochemical demonstration of intracellular antigen expression (indicated by the presence of red colouration) by $R$. salmoninarum in infected EPC cultures ( $21 \mathrm{~d}$ after inoculation). (a) Expression of p57. A large number of cells show positive staining, which appears mainly as a diffuse material scattered in the cytoplasm and, to a lesser extent, as small particles. (b) Expression of haemolysin. Immuno-positive material shows a restricted distribution in the EPC monolayer and most intracellular staining appears as particulate material. Some cells contain large amounts of the positive material clustered in one cell pole. (c) Cytolysin expression. The distribution of the staining for this antigen resembles that described for haemolysin. Note the cell (arrow) containing a large spot of positive material. Bars, $20 \mu \mathrm{m}$. 
Table 2. Mortality and infection levels in rainbow trout after challenge with three different doses of $R$. salmoninarum FT10 grown on mSKDM or in EPC cultures

\begin{tabular}{|lcc|}
\hline $\begin{array}{l}\text { Challenge dose } \\
\text { (c.f.u. per fish) }\end{array}$ & $\begin{array}{c}\text { No. of mortalities } \\
(/ \mathbf{1 0})\end{array}$ & $\begin{array}{c}\text { No. of non-lethal } \\
\text { infections }(/ \mathbf{1 0})^{*}\end{array}$ \\
\hline $3.5 \times 10^{5} \dagger$ & 7 & 3 \\
$3.5 \times 10^{4} \dagger$ & 2 & 7 \\
$3.5 \times 10^{3} \dagger$ & 0 & 2 \\
$2 \cdot 0 \times 10^{5} \ddagger$ & 10 & - \\
$2 \cdot 0 \times 10^{4} \ddagger$ & 9 & 1 \\
$2 \cdot 0 \times 10^{3} \ddagger$ & 4 & 6 \\
\hline
\end{tabular}

* Non-lethal infection levels were determined by bacteriological examination of the survivors at the end of the 8 week challenge period.

† Cells were cultured for $21 \mathrm{~d}$ on $\mathrm{mSKDM}$ at $15^{\circ} \mathrm{C}$.

$\ddagger$ Cells were cultured for $21 \mathrm{~d}$ in EPC monolayers at $18^{\circ} \mathrm{C}$ in $5 \%$ $\mathrm{CO}_{2}$.

\section{Expression of antigens intracellularly}

Western blotting (data not shown) and immunohistochemistry revealed the presence of large quantities of p57 antigen located intracellularly in infected cultures. The immuno-positive material was observed to be particulate (associated with bacterial cells) and secreted (soluble material), and widely distributed throughout the monolayer (Fig. 2a). A comparison of equivalent cultures, i.e. those produced from the same infected flask and immunostained at the same stage after infection using anti-haemolysin and anti-cytolysin antisera, showed the presence of these antigens in infected cultures but at much lower levels than that of the $\mathrm{p} 57$ antigen. In contrast to the p57 antigen, detection of cytolysin (encoded by $h l y$ ) and haemolysin (encoded by $r s h)$ was characterized by particulate immuno-positive material which was limited to discrete areas of the monolayer. The focal distribution of the intracellular staining, sometimes forming large round spots in one pole of the EPC cells, suggested that most bacteria expressing such antigens were clustered into intracellular vesicles (Fig. $2 b$ and c) which agrees with the ultrastructural observations showing that bacterial cells were clustered into vesicles.

\section{Comparative virulence of $R$. salmoninarum grown in EPC cells and on mSKDM}

Table 2 shows the results of the challenge experiments performed with $R$. salmoninarum cells which had been cultured either on mSKDM plates or in EPC cells. It is apparent from the mortality levels that bacteria cultured in EPC cells displayed increased virulence, as indicated by the greater number of deaths and the level of nonlethal infections. Thus, fish challenged with the highest dose of bacteria $\left(2.0 \times 10^{5}\right.$ cells per fish) grown in EPC cells began to die within 4 weeks of challenge, with $100 \%$ mortality recorded within 5 weeks post inoculation. In contrast, the first mortalities among the fish challenged with $3.5 \times 10^{5}$ cells (grown on $\mathrm{mSKDM}$ ) per fish were not recorded until 6 weeks after challenge (Table 2).

\section{DISCUSSION}

Despite numerous publications employing biochemical, immunological and molecular genetic approaches to the study of virulence factors, the pathogenesis of $R$. salmoninarum is still poorly understood (see Evenden $e t$ al., 1993). It is clear that the fastidious nature of the bacterium and the inability to produce cultures which truly resemble the in vivo form of the pathogen are central to this lack of knowledge. This study sought to overcome some of the limitations which are inherent when an intracellular pathogen is cultured in vitro. The rationale behind the research was to combine the various strands of information that have been compiled on the virulence mechanisms of $R$. salmoninarum, using the experimental approaches described above, and apply them to an in vitro tissue culture model. In spite of the limitations associated with the use of cultured cells in the examination of bacterial pathogens, this technique has been used to great effect in the study of numerous bacterial diseases of mammals (Salyers \& Whitt, 1994). In fact, the cell culture model developed here was not the first attempt to use tissue culture in the study of $R$. salmoninarum. Previously, Maulén et al. (1996) reported the presence of a putative invasin protein encoded by $R$. salmoninarum, which allowed the infection of CHSE cells with recombinant $E$. coli HB101. Moreover, Flaño et al. (1996a) used primary explant cultures of rainbow trout gills in an examination of fish tissue response to infection with $R$. salmoninarum. In contrast to these earlier studies, the EPC model developed here was designed to allow the reproducible culture of $R$. salmoninarum and to examine the possibility that this culture method might induce the expression of putative virulence factors in response to intracellular growth.

Data obtained from preliminary experiments resulted in the establishment of an infection protocol that permitted the convenient and reproducible culture of $R$. salmoninarum in EPC cells. Additional experiments examined the use of salmonid cell lines, including RTG2 and polymorphic cultures derived from rainbow trout pronephros. However, these cultures did not give the same level of reproducibility as infection of EPC cells (data not shown). The mechanism by which the pathogen is capable of infecting EPC cells was not established in this study. However, the findings of Maulén et al. (1996) suggest the involvement of invasin molecules. The infections were characterized by a low initial rate of bacterial entry into the culture. This limited infection may reflect the nature of EPC cells, since they are cyprinid in origin, and $R$. salmoninarum has been reported to be incapable of causing disease in cyprinid 
fish (Sakai et al., 1989). Alternatively, the use of bacteria grown as plate cultures, which may not be expressing receptor or invasin molecules, as the source of inocula may explain this observation. This possibility is supported by the results from the comparative virulence study confirming the long-held theory that culture (in this case only one generation) on plates of nutrient-rich media exerts detrimental effects upon the virulence of $R$. salmoninarum (Bruno \& Munro, 1986; Bell et al., 1988). Furthermore, data from the examination of survivors for $R$. salmoninarum demonstrated the increased infectivity of EPC-grown cells. In particular, it was observed that only $20 \%$ of fish infected with $3.5 \times 10^{3}$ mSKDM-grown cells per fish were harbouring the pathogen, in comparison with $100 \%$ of the fish challenged with an equivalent dose of EPC-grown pathogen. Indeed, $40 \%$ mortality was observed in this group. We attempted to infect EPC cells with the $R$. salmoninarum type strain ATCC 33209 , but were unable to infect cells even with a challenge of $1 \times 10^{9}$ cells. However in vivo studies have also shown that such a challenge of this strain is unable to induce disease in rainbow trout, whereas FT10 can induce disease with challenges as low as $1 \times 10^{3}$ cells. Clearly further studies on a greater number of isolates, particularly those with established levels of virulence, are necessary to further establish the observation made here.

The use of immunohistochemical techniques to examine the expression of $\mathrm{p} 57$, cytolysin and haemolysin demonstrated that these molecules were produced when $R$. salmoninarum was grown intracellularly in EPC cells. It appears that, in common with the in vivo situation (Turaga et al., 1987), p57 is produced and secreted in large quantities in infected EPC cells. However, the absence of any discernible cytotoxic effect in infected cultures would indicate that, in common with p57 produced and recovered from broth or plate cultures (Bandín et al., 1991), this molecule, when produced intracellularly, does not exhibit any measurable biological effect upon cultured fish cells.

The detection of cytolysin and haemolysin gene products in infected EPC shows that the hly and rsy genes are expressed in response to intracellular stimuli. Indeed, it has been reported that specific antibodies towards these proteins are produced in salmonids naturally infected with $R$. salmoninarum, demonstrating their production in vivo in the course of BKD (Grayson, 1993). The observation that only a limited proportion of intracellular bacteria were expressing haemolysin and cytolysin in the cell culture model suggests that these molecules have highly specific functions. These antigens were detected in association with bacterial cells and, according to the results from the ultrastructural and immunochemical studies, such bacteria were generally contained within cytoplasmic vesicles. It may be that the production of these two proteins is a central feature for the establishment and persistence of intracellular infections and may act by contact-induced membrane damage leading to vesicle fusion and the formation of the large cystic cavities, as observed in heavily infected cells. On the basis of amino acid sequence and Western blotting data, Grayson et al. (1995a, b) suggested that both molecules are likely to be surface-expressed. This idea is supported by the lack of haemolytic and cytotoxic activity reported for the EP of this pathogen (Bandín et al., 1991). Additional evidence for this possibility is provided by electron microscopy data where the pathogen is observed to be in intimate contact with endosome membranes and could conceivably use this contact to disrupt the integrity of the membrane and infect the cytoplasm. The presence of the cystic cavities containing large quantities of $R$. salmoninarum cells observed in infected EPC cultures bears some similarity to the reported survival and proliferation of Salmonella within altered, spacious or loose phagosomes (Alpuche-Aranda et al., 1994). Interestingly, there was only limited evidence for this phenomenon in the renal and splenic haemopoietic tissues or thymus of coho salmon (Oncorbynchus kisutch) inoculated with $R$. salmoninarum (Flaño et al., 1996b, c). Thus, the formation of cystic cavities may be peculiar to this specific cell type or possibly reflects the in vitro nature of the EPC model.

In conclusion, this study has developed a novel in vitro cell culture technique which permits the intracellular production of $R$. salmoninarum antigens and virulence factors which are more likely to be representative of those produced by the pathogen in vivo. Infected cultures can be used to produce bacteria for use in infectivity experiments as well as offering a source of material for biochemical and immunological study. Moreover, in comparison with plate culture of the pathogen, the use of the EPC cell culture model allows the maintenance of virulence and the production of factors involved in the pathogenesis of BKD.

\section{ACKNOWLEDGEMENTS}

The financial support of EU contract AIR-CT92-0036 and the Home Office is gratefully acknowledged.

\section{REFERENCES}

Alpuche-Aranda, C. M., Racoosin, E. L., Swanson, J. A. \& Miller, S. I. (1994). Salmonella stimulate macrophage macropinocytosis and persist within spacious phagosomes. J Exp Med 179, 601-608.

Austin, B. \& Austin, D. A. (1993). Bacterial Fish Pathogens: Disease in Farmed and Wild Fish, 2nd edn. Chichester: Ellis Horwood.

Austin, B., Embley, T. M. \& Goodfellow, M. (1983). Selective isolation of Renibacterium salmoninarum. FEMS Microbiol Lett 17, 111-114.

Bandín, I., Santos, Y., Barja, J. L. \& Toranzo, A. E. (1989). Influence of the growth conditions on the hydrophobicity of Renibacterium salmoninarum evaluated by different methods. FEMS Microbiol Lett 60, 71-78.

Bandín, I., Santos, Y., Bruno, D. W., Raynard, R. S., Toranzo, A. E. \& Barja, J. L. (1991). Lack of biological activities in the extracellular products of Renibacterium salmoninarum. Can J Fish Aquat Sci 48, 421-425. 
Bell, G. R., Traxler, G. S. \& Dworschak, C. (1988). Development in vitro and pathogenicity of an erythromycin-resistant strain of Renibacterium salmoninarum, the causative agent of bacterial kidney disease in salmonids. Dis Aquat Org 4, 19-25.

Bruno, D.W. \& Munro, A. L. S. (1986). Uniformity in the biochemical properties of Renibacterium salmoninarum isolates obtained from several sources. FEMS Microbiol Lett 33, 247-250.

Daly, J. G. \& Stevenson, R. M. W. (1987). Hydrophobic and haemagglutinating properties of Renibacterium salmoninarum. $J$ Gen Microbiol 133, 3575-3580.

Daly, J. G. \& Stevenson, R. M. W. (1989). Agglutination of salmonid spermatozoa by Renibacterium salmoninarum. J Aquat Anim Health 1, 163-164.

Daly, J. G. \& Stevenson, R. M. W. (1990). Characterization of the Renibacterium salmoninarum haemagglutinin. J Gen Microbiol 136, 949-953.

Evelyn, T. P. T. (1993). Bacterial kidney disease-BKD. In Bacterial Diseases of Fish, pp. 177-195. Edited by V. Inglis, R. J. Roberts \& N. R. Bromage. Oxford: Blackwell.

Evelyn, T. P. T., Bell, G. R., Prosperi-Porta, L. \& Ketcheson, J. E. (1989). A simple technique for accelerating the growth of the kidney disease bacterium Renibacterium salmoninarum on a commonly used culture medium (KDM2). Dis Aquat Org 7, 231-234.

Evenden, A. J., Gilpin, M. L. \& Munn, C. B. (1990). The cloning and expression of a gene encoding haemolytic activity from the fish pathogen Renibacterium salmoninarum. FEMS Microbiol Lett 71, 31-34.

Evenden, A. J., Grayson, T. H., Gilpin, M. L. \& Munn, C. B. (1993). Renibacterium salmoninarum and bacterial kidney disease - the unfinished jigsaw. Annu Rev Fish Dis 3, 87-104.

Flaño, E., López-Fierro, M. P., Razquin, B. E. \& Villena, A. (1996a). Renibacterium salmoninarum infected gill cultures from rainbow trout. Fish Shellfish Immunol 6, 173-184.

Flaño, E., López-Fierro, P., Razquin, B., Kaattari, S. L. \& Villena, A. (1996b). Histopathology of the renal and splenic haemopoietic tissues of coho salmon Oncorbynchus kisutch experimentally infected with Renibacterium salmoninarum. Dis Aquat Org 24, 107-115.

Flaño, E., Kaattari, S. L., Razquin, B. \& Villena, A. (1996c). Histopathology of the thymus of coho salmon Oncorbynchus kisutch experimentally infected with Renibacterium salmoninarum. Dis Aquat Org 26, 11-18.

Fryer, J. L. \& Sanders, J. E. (1981). Bacterial kidney disease of salmonid fish. Annu Rev Microbiol 35, 273-298.

Getchell, R. G., Rohovec, J. S. \& Fryer, J. L. (1985). Comparison of Renibacterium salmoninarum isolates by antigen analysis. Fish Pathol 20, 149-159.

Grayson, T. H. (1993). Molecular cloning and characterisation of potential vaccine antigens from Renibacterium salmoninarum. $\mathrm{PhD}$ thesis, University of Plymouth, UK.

Grayson, T. H., Evenden, A. J., Gilpin, M. L. \& Munn, C. B. (1995a). A gene from Renibacterium salmoninarum encoding a product which shows homology to bacterial zinc-metalloproteases. Microbiology 141, 1331-1341.
Grayson, T. H., Evenden, A. J., Gilpin, M. L. \& Munn, C. B. (1995b). Production of Renibacterium salmoninarum hemolysin fusion protein in Escherichia coli K12. Dis Aquat Org 22, 153-156.

Griffiths, S. G., Olivier, G., Fildes, J. \& Lynch, W. H. (1991). Comparison of western blot, direct fluorescent antibody and drop plate culture methods for the detection of Renibacterium salmoninarum in Atlantic salmon (Salmo salar L.). Aquaculture 97, 117-129.

Gutenberger, S. K. (1993). Phylogeny and intracellular survival of Renibacterium salmoninarum. PhD thesis, Oregon State University, USA.

Kaattari, S., Getchell, R., Turaga, P., Irwin, M. \& Wiens, G. (1986). Development of a Vaccine for Bacterial Kidney Disease in Salmon. Annual Report 1985. Portland: US Department of Energy, Bonneville Power Administration, Division of Fish and Wildlife.

McIntosh, D. \& Austin, B. (1996). The validity of western blotting for the diagnosis of bacterial kidney disease based on the detection of the p57 antigen of Renibacterium salmoninarum. J Microbiol Methods 25, 329-335.

Maulén, N. P., Morales, P. J., Aruti, D., Figueroa, J. E., Concha, M. I., Krauskopf, M. \& León, G. (1996). Identification of a Renibacterium salmoninarum DNA fragment associated with bacterial internalization into CHSE-cultured cells. FEMS Microbiol Lett $135,37-43$.

Rose, A. S. \& Levine, R. P. (1992). Complement mediated opsonisation and phagocytosis of Renibacterium salmoninarum. Fish Shellfish Immunol 2, 223-240.

Sakai, M., Ogasawara, F., Atsuta, S. \& Kobayashi, M. (1989). Comparative sensitivity of carp Cyprinus carpio $\mathrm{L}$ and rainbow trout Salmo gairdneri Richardson, to Renibacterium salmoninarum. J Fish Dis 12, 367-372.

Salyers, A. A. \& Whitt, D. D. (1994). Bacterial Pathogenesis: a Molecular Approach. Washington, DC: American Society for Microbiology.

Turaga, P., Wiens, G. \& Kaattari, S. (1987). Bacterial kidney disease: the potential role of soluble protein antigen(s). J Fish Biol Suppl A 31, 191-194.

Wiens, G. D. \& Kaattari, S. (1989). Monoclonal antibody analysis of common surface protein(s) of Renibacterium salmoninarum. Fish Pathol 24, 1-7.

Wiens, G. D. \& Kaattari, S. L. (1991). Monoclonal antibody characterization of a leuko-agglutinin produced by Renibacterium salmoninarum. Infect Immun 59, 631-637.

Wolke, R. E. (1975). Pathology of bacterial and fungal disease affecting fish. In The Pathology of Fishes, pp. 76-78. Edited by W. E. Ribelin \& G. Migaki. Madison: University of Wisconsin Press.

Young, C. L. \& Chapman, G. B. (1978). Ultrastructural aspects of the causative agent and renal histopathology of bacterial kidney disease in brook trout (Salvelinus fontinalis). J Fish Res Board Can 35, 1234-1248.

Received 16 January 1997; revised 15 May 1997; accepted 30 June 1997. 